\title{
Habitat connectivity as a factor affecting fish assemblages in temperate reefs
}

\author{
T. Vega Fernández ${ }^{1, *}$, G. D'Anna ${ }^{1}$, F. Badalamenti ${ }^{1}$, A. Pérez-Ruzafa ${ }^{2}$ \\ ${ }^{1}$ CNR - IAMC, Marine Ecology Laboratory, Via G. da Verrazzano, 17 - 91014 Castellammare del Golfo (TP), Italy \\ ${ }^{2}$ Department of Ecology and Hydrology, University of Murcia, Campus Universitario de Espinardo, 30100 Murcia, Spain
}

\begin{abstract}
Habitat connectivity exerts a significant effect on the structure of biological communities. However, it is generally difficult to study such an effect while controlling for other specific components of habitat structure. Here, temperate fish assemblages were studied in artificial reefs in localities differing chiefly in connectivity among complex habitat patches. Total fish abundance and biomass were higher in localities with high habitat connectivity, while species evenness followed the opposite trend. In most cases, the assemblages can also be distinguished by composition and relative abundance of species, as well as multispecies variability. Species responses were related to specific ecological profiles. Small species and those with restricted mobility were associated with high habitat connectivity. By contrast, medium-sized, off-reef foragers and vagile species were associated with reef isolation. The abundance ratio between 2 representative families of both groups of species, labrids and sparids, confirmed this finding. The temporal consistency of the observed patterns was also studied. The assemblages differed between periods of the year in terms of species composition and relative abundances. Total fish abundance, number of species and evenness were higher during the cold period than the warm, due to the presence of transient species. The results highlight the importance of habitat connectivity for the conservation and management of Mediterranean reef fishes.
\end{abstract}

KEY WORDS: Habitat structure $\cdot$ Habitat connectivity $\cdot$ Habitat suitability $\cdot$ Population persistence Artificial reefs $\cdot$ Sparids $\cdot$ Labrids $\cdot$ NW Mediterranean

\section{INTRODUCTION}

Fishes move to exploit resources, principally food and shelter. As a general rule, fishes select foraging areas to maximize food intake where proper shelter is available. Some reef fishes move from shelters to feed on sandy areas, mangroves or seagrass beds nearby (Hobson 1972, Beets et al. 2003), and in some cases they cross bare areas to reach feeding grounds. The extent of the sand matrix has been reported to exert an important effect on the fish assemblages associated with both natural (Ault \& Johnson 1998a) and artificial reefs (Walsh 1985, Nanami \& Nishihira 2003b). It follows that the degree of connectivity, or isolation, among reefs and other suitable habitats is a principal landscape feature affecting the coastal reef fish assemblage structure through post-settlement relocation of individuals (Jones 1988, Lewis 1997, Dorenbosch et al. 2007). Habitat connectivity is used here as a function of both distance to suitable habitat patches and the abundance and size of those patches.

While some reef species move over bare sand for feeding (Ambrose \& Anderson 1990, Langlois et al. 2005), others are reluctant to cross it (Coll et al. 1998, Chapman \& Kramer 2000). Extensive sand patches may be perceived as barriers of variable permeability in relation to the size and vagility of fish species (Bell \& Westoby 1986, Stamps et al. 1987, Coll et al. 1998), with medium-sized fish being the least influenced by a high degree of reef isolation or low habitat connectivity (Ault \& Johnson 1998a, McClanahan \& Mangi 2000).

The influence of habitat connectivity or isolation on fish assemblages is best known in tropical reefs (e.g. Robertson 1988, Ault \& Johnson 1998a, Dorenbosch et 
al. 2007). However, the unambiguous identification of causal factors through habitat manipulation has been restricted to small-scale experiments (100s of meters) because the natural variability of the environment limits proper replication (Belmaker et al. 2005). By contrast, large-scale observational experiments are difficult to interpret because many environmental factors appear correlated in nature. This is particularly the case for the degree of connectivity among habitat patches and their sizes (Fahrig 2003). Identical artificial reefs are powerful tools for overcoming these problems, and facilitate the identification of ecological patterns that are otherwise difficult to elucidate in natural habitats (Miller 2002). Nevertheless, artificial reefs may reflect local environmental conditions to some extent, and it is not possible to completely exclude the influence of every site-related factor on the composition and abundance of the associated biotic community.

Among the characteristic families of reef fishes, labrids and sparids are well represented in temperate seas and are among the most speciose groups in Mediterranean coastal assemblages (Harmelin 1987, Guidetti 2000). Benthic dwelling species belonging to these 2 families show different home ranges in rough concordance with body size. Many labrids and sparids move across patches of different habitat type (rock, sand and seagrasses) during their daily activity, but the former are attached to small areas while the latter cover larger spaces (Harmelin 1987). The probability that an individual fish locates a reef is expected to increase with habitat connectivity and also with fish vagility, which determines the rate of fish relocation among habitat patches. The structure of the reef assemblage is affected by the migration of individuals from outer parts (Robertson 1988, Lewis 1997), especially where there is high local mortality (Talbot et al. 1978). Thus, localities differing in habitat connectivity are expected to present distinct structures of reef fish assemblages in terms of species composition and of their relative abundances. The predicted pattern is also expected to vary throughout the year in relation to reproductive (Lewis 1997) and ontogenic (Lewis 1997, MacPherson 1998) migrations, as well as to movements following changes in water temperature (Ebeling \& Hixon 1991).

The aim of this study was to assess the effect of habitat connectivity on Mediterranean coastal fishes, taking advantage of the possibilities for manipulation offered by artificial reefs. In particular, the hypo- theses were the following: (1) fish assemblages will differ among reef areas presenting different connectivity with the surrounding complex habitats; (2) this pattern will vary throughout the year; and (3) benthivore sparids will be more abundant than labrids in the most isolated reef areas, and the opposite will be the case in the reef areas best connected to other complex habitat patches.

\section{MATERIALS AND METHODS}

Study area. Three artificial reef areas (ARAs) were selected along the NW coast of Sicily (Italy), at Alcamo Marina (AM), Balestrate (BA) and Vergine Maria (VM). AM-ARA and BA-ARA were located in the Gulf of Castellammare $\left(38^{\circ} 03^{\prime} \mathrm{N}, 012^{\circ} 54^{\prime} \mathrm{E}\right)$ and VM-ARA on the eastern side of the Gulf of Palermo $\left(38^{\circ} 07^{\prime} \mathrm{N}\right.$, $013^{\circ} 26^{\prime} \mathrm{E}$ ) (Fig. 1). The reefs were made up of pyramid-shaped sets of 14 concrete cubes each, deployed on soft bottoms at intervals of approximately $50 \mathrm{~m}$. All reefs were at a depth of 16 to $22 \mathrm{~m}$ and had been in place for more than $9 \mathrm{yr}$. The pyramid structures were identical in the 3 locations, providing control for the effects of structural complexity. AM-ARA was composed of 32 pyramids distributed roughly linearly, while BA-ARA and VM-ARA had 9 and 6 pyramids respectively, in quadrangular arrangement. Water turbidity is relatively high for the region (annual mean 9.00 nephelometer turbidity units [NTU] \pm 3.81 [SD], V. M. Giacalone unpubl. data), mainly due to silt input from run-off (D'Anna et al. 2000). Maximum turbidity

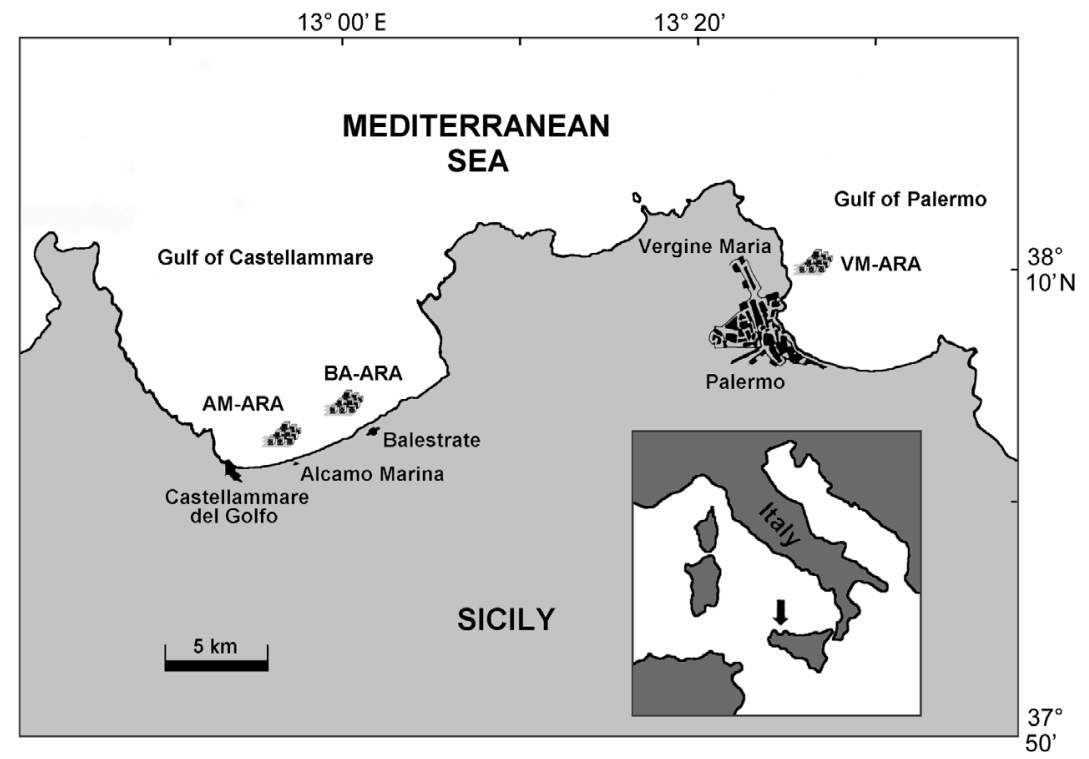

Fig. 1. Study area. Location of the artificial reef areas (ARA) along the northwestern coast of Sicily. AM-ARA: Alcamo Marina ARA; BA-ARA: Balestrate ARA, both in the Gulf of Castellammare. VM-ARA: Vergine Maria ARA, in the Gulf of Palermo 
was found at AM-ARA and slighly decreased toward VM-ARA, while BA-ARA showed intermediate values. Percentage of macroalgal coverage of each pyramid was visually estimated from video recordings made during the study. Macroalgal coverage ranged between 80 and $100 \%$ at VM-ARA, 10 and $30 \%$ at AMARA and $0 \%$ at BA-ARA. The algal community was dominated by brown algae, mainly Cystoseira spp., Sargassum spp. and Halopteris spp. (D'Anna et al. 2000) on horizontal surfaces and Halopteris spp. and the red algae Peyssonnelia spp. on vertical surfaces of the blocks. Polychaete serpulids, bivalves and bryozoans were the dominant taxa of BA-ARA.

The 3 ARAs presented different degrees of connectivity among complex habitat patches, intended as estimated mean patch size and mean inter-patch distance, within an area of $1 \mathrm{~km}^{2}$. The AM-ARA was located on an extensive muddy-sandy bottom. Distance from the sandy coastline was $1500 \mathrm{~m}$ and the nearest complex habitat was the rocky western coast at a distance of nearly $4.5 \mathrm{~km}$. The BA-ARA was located on a sandy bottom with scattered patches of rocks and the seagrass Posidonia oceanica. Patches were relatively small (between 1 and $2 \mathrm{~m}^{2}$ ), and distances to the closest neighbour ranged between 10 and $100 \mathrm{~m}$. The coastline was itself a rocky habitat $600 \mathrm{~m}$ from the ARA. The VM-ARA was on a sandy bottom with abundant rocky outcrops and $P$. oceanica beds. These habitat patches were relatively large (between 10 and $100 \mathrm{~m}^{2}$ ) and the sandy matrix extended between them from 1 to 10s of meters. The rocky coast was $200 \mathrm{~m}$ from the ARA. The mean fish density around the ARAs was estimated to be $0.01 \pm 0.03$ ind. $\mathrm{m}^{-2}$ from line transects $(5$ by $50 \mathrm{~m}$ ) made at a similar depth and about $100 \mathrm{~m}$ from the artificial reef edge in each location. Since the surrounding fish density did not differ among the ARAs studied (1-way ANOVA; $\mathrm{n}=6 ; F_{2,15}=0.46$; $\mathrm{p}=0.6384$ ), these censes were not further repeated. Mean water temperature ranges from $22.3 \pm 0.2^{\circ} \mathrm{C}(\mathrm{SD})$ in summer to $14.5 \pm 0.1^{\circ} \mathrm{C}$ in winter at $13 \mathrm{~m}$ depth (V. M. Giacalone unpubl. data).

Experimental design. The structure of the fish assemblages among the ARAs in different localities was compared, considering 3 levels: AM, with low habitat connectivity; BA, with medium habitat connectivity; and VM, with high habitat connectivity. Locality was treated as a fixed factor, as no other ARAs of identical structure and in similar environmental conditions were present. Period was included as a second crossed factor, treated as fixed with 2 levels: Warm (WA), in June and July; and Cold (CO), in December and January. These periods were considered representative of the annual variability in the local fish assemblages, while weather conditions permitted field sampling.
Sampling procedures. Within each period, the fish assemblages of different pyramids were censed. Fish counts were assumed to be independent even when the same reef was censed in both periods, due to the high turnover of the assemblages studied (authors' pers. obs.). Visual censes of the fish assemblages were carried out using a circular transect around the reef and a point count on the top. In this study, the same observer recorded all samples, carefully screening all reef sets in order to include all detectable reef fishes (mean abundance $=537.89 \pm 410.68$ [SD]). Six censuses were conducted between 09.00 and $12.00 \mathrm{~h}$ during summer and winter 1998. Species abundances were estimated in classes following a geometric progression of base approximately 2, and individual total length (TL) estimated to the nearest $\mathrm{cm}$. Total biomass was then obtained by means of (log-transformed) length-weight linear regressions. Parameters were computed for each species from measurements on a large number of individuals fished in the Gulf of Castellammare (18 species), or applying published parameters from the closest area (20). For those species for which no data were available (7), average values were estimated from closely related species or theoretically approximated to $a=0.01$ and $b=3$.

Data analysis. Multivariate abundance data were log-transformed and similarity matrices constructed on the basis of Bray-Curtis dissimilarities. The potential pattern in relation to the factors considered was visualized through constrained ordination, and the validity of the trend obtained was then tested by canonical discriminant analysis (CDA). Techniques for multivariate analysis of variance (PERMANOVA) and multivariate dispersion (PERMDISP) were also used to determine the significance of the experimental factors.

In addition, univariate ANOVAs were computed on the number of species $(S)$, the Shannon diversity index ( $H^{\prime}$, based on natural logarithms), the Simpson index of dominance $(\lambda)$, the modified Hill's evenness ratio $\left(N_{21}\right.$, Alatalo 1981), the total number of individuals $\left(N_{\mathrm{T}}\right)$ and the total estimated biomass in $g\left(B_{\mathrm{T}}\right)$. The ratio $\left(N_{\mathrm{L} / \mathrm{S}}\right)$ between the abundances of labrids (Coris julis, Symphodus rostratus, S. cinereus, S. doiderleini, $S$. mediterraneus, $S$. melanocercus, $S$. ocellatus, S. roissali, S. tinca and Thalassoma pavo) and benthivore sparids (Diplodus annularis, D. sargus, D. vulgaris, Lithognathus mormyrus, Pagellus acarne, Pagrus pagrus and Spondyliosoma cantharus) was also analyzed.

Homogeneity of variances in the univariate data sets were checked by Cochran's $C$-tests, and assumptions about normality were avoided by computing all tests by permutation of adequate units. Canonical correlation analysis (CCA) was plotted to further explore which species were mainly responsible for the results obtained. To this end, 2 new distance matrices were 
Table 1. Results of the canonical discriminant analysis (CDA) exploring the effects of Locality and Period on the fish assemblage associated with artificial reefs, based on log-transformed fish abundances and Bray-Curtis dissimilarities. m: number of principal coordinate axes. Allocation success: percentage of points correctly allocated to each group. $\delta^{2}$ : squared canonical correlation coefficient; AM: Alcamo Marina; BA: Balestrate; VM: Vergine Maria; WA: warm period; CO: cold period. Bold numbers indicate significant results with $\mathrm{p}<0.05$ after 9999 random permutations

\begin{tabular}{|c|c|c|c|c|c|c|c|}
\hline \multirow[t]{2}{*}{ Factor } & \multirow[t]{2}{*}{$m$} & \multicolumn{4}{|c|}{ - Allocation success (\%) } & \multirow[t]{2}{*}{$\delta^{2}$} & \multirow[t]{2}{*}{$\mathrm{p}$} \\
\hline & & Group 1 & Group 2 & Group 3 & Total & & \\
\hline Locality & 9 & $100.00(\mathrm{AM})$ & 100.00 (BA) & $100.00(\mathrm{VM})$ & 100.00 & 0.97 & 0.0001 \\
\hline Period & 4 & 100.00 (WA) & 94.44 (CO) & & 97.22 & 0.85 & 0.0001 \\
\hline
\end{tabular}

compiled. One was based on Bray-Curtis dissimilarities on the log-transformed abundances of those species that showed an absolute correlation value of over 0.3 with at least one of the canonical axes, and present in at least 9 samples. The second matrix was based on Euclidean distances and calculated on the following environmental variables: distance $(\mathrm{m})$ from the coast (DC), distance (m) from Posidonia oceanica beds (DPO) and from rocks (DR); mean connectivity within the artificial reef, expressed as the mean number of other neighbouring artificial reef units within a radius of $50 \mathrm{~m}$ (MCAR); and the mean temperature in ${ }^{\circ} \mathrm{C}(T)$ (see Fig. 4).

\section{RESULTS}

A total of 45 species belonging to 19 families were censed. Twelve species were recorded exclusively in one period and were classified as transients. The remaining 33 species were considered to form persistent populations (Appendix 1).

The permutation test of CDA yielded a strongly significant separation among the groups considered (Table 1). The fish assemblages differed significantly in the interaction of Locality and Period in terms of species composition and relative abundances (Table 2), as well as in multivariate dispersion (Table 3). The posthoc paired comparisons detected significant differences between nearly all assemblages, the only excep-

Table 2. Permutational multivariate analysis of variance (PERMANOVA) based on log-transformed fish abundances and Bray-Curtis dissimilarities. Bold numbers indicate significant results with $\mathrm{p}<0.05$ after 9999 random permutations

\begin{tabular}{|lrrrrc|}
\hline Source & df & \multicolumn{1}{c}{ SS } & MS & \multicolumn{1}{c|}{$F$} & $\mathrm{p}$ \\
\hline Locality & 2 & 16982.34 & 8491.17 & 5.30 & $\mathbf{0 . 0 0 5 0}$ \\
Period & 1 & 4736.92 & 4736.92 & 8.91 & $\mathbf{0 . 0 0 0 2}$ \\
Locality $\times$ Period & 2 & 3203.52 & 1601.76 & 3.01 & $\mathbf{0 . 0 0 5 7}$ \\
Residual & 30 & 15951.44 & 531.71 & & \\
Total & 35 & 40874.22 & & & \\
\hline
\end{tabular}

Table 3. Permutational test of multivariate dispersion (PERMDISP) based on log-transformed fish abundances and Bray-Curtis dissimilarities. Bold numbers indicate significant results with $\mathrm{p}<0.05$ after 9999 random permutations

\begin{tabular}{|lccccc|}
\hline Source & df & SS & MS & $F$ & $\mathrm{p}$ \\
\hline Locality & 2 & 467.19 & 233.59 & 1.92 & 0.3384 \\
Period & 1 & 367.07 & 367.07 & 37.52 & $\mathbf{0 . 0 0 0 2}$ \\
Locality $\times$ Period & 2 & 243.03 & 121.52 & 12.42 & $\mathbf{0 . 0 0 0 3}$ \\
Residual & 30 & 293.48 & 9.78 & & \\
Total & 35 & 1370.77 & & & \\
\hline
\end{tabular}

Table 4. Post-hoc paired comparisons of location of data centroids and data dispersion among experimental groups (Locality $\times$ Period). Uncorrected $t$-test based on log-transformed fish abundances and Bray-Curtis dissimilarities. AM: Alcamo Marina; BA: Balestrate; VM: Vergine Maria; WA: warm period; CO: cold period. Bold numbers indicate significant results with $\mathrm{p}<0.05$ after 9999 random permutations

\begin{tabular}{|lccc|}
\hline Groups & $t$ & $\mathrm{p}$ & $\begin{array}{c}\text { No. of unique } \\
\text { permutations }\end{array}$ \\
\hline Location & & & \\
AM vs. BA (within WA) & 3.41 & $\mathbf{0 . 0 0 0 1}$ & 462 \\
AM vs. VM (within WA) & 4.85 & $\mathbf{0 . 0 0 0 1}$ & 462 \\
BA vs. VM (within WA) & 3.78 & $\mathbf{0 . 0 0 0 5}$ & 462 \\
AM vs. BA (within CO) & 1.19 & 0.2272 & 462 \\
AM vs. VM (within CO) & 2.66 & $\mathbf{0 . 0 0 2 0}$ & 462 \\
BA vs. VM (within CO) & 3.25 & $\mathbf{0 . 0 0 0 3}$ & 462 \\
WA vs. CO (within AM) & 2.0772 & $\mathbf{0 . 0 1 1 0}$ & 461 \\
WA vs. CO (within BA) & 2.1557 & $\mathbf{0 . 0 0 2 4}$ & 461 \\
WA vs. CO (within VM) & 2.6357 & $\mathbf{0 . 0 0 2 2}$ & 461 \\
Dispersion & & & \\
AM vs. BA (within WA) & 5.25 & $\mathbf{0 . 0 0 2 3}$ & 462 \\
AM vs. VM (within WA) & 1.83 & 0.0948 & 462 \\
BA vs. VM (within WA) & 3.65 & $\mathbf{0 . 0 0 5 8}$ & 462 \\
AM vs. BA (within CO) & 2.44 & $\mathbf{0 . 0 4 0 6}$ & 462 \\
AM vs. VM (within CO) & 6.18 & $\mathbf{0 . 0 0 2 0}$ & 462 \\
BA vs. VM (within CO) & 4.78 & $\mathbf{0 . 0 0 2 3}$ & 462 \\
WA vs. CO (within AM) & 3.76 & $\mathbf{0 . 0 0 5 0}$ & 461 \\
WA vs. CO (within BA) & 7.97 & $\mathbf{0 . 0 0 1 8}$ & 461 \\
WA vs. CO (within VM) & 0.64 & 0.5243 & 461 \\
\hline
\end{tabular}




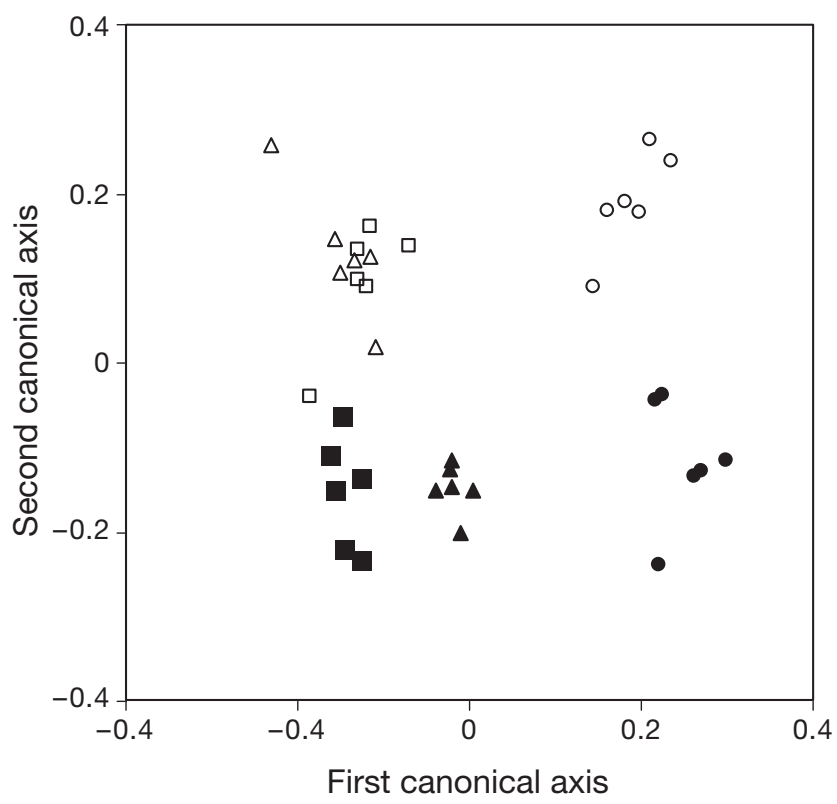

Fig. 2. Ordination plot of the samples using canonical discriminant analysis (CDA), based on log-transformed fish abundances and Bray-Curtis dissimilarities. Locations: squares (Alcamo Marina); triangles (Balestrate); circles (Vergine Maria). Periods: black (warm); white (cold)

tion being those in $\mathrm{AM}$ and $\mathrm{BA}$ reefs during the cold period (Table 4). These differences were attributed to species composition and changes in the relative abundances. However, multivariate data dispersion also accounted for the differences found in most cases (Table 4). These findings confirm the pattern plotted by the CDA (Fig. 2).

All univariate descriptors of the fish assemblages $(S$, $H^{\prime}, \lambda, N_{21}, N_{\mathrm{T}}, N_{\mathrm{L} / \mathrm{S}}$ and $B_{\mathrm{T}}$ ) matched homocedasticity after logarithmic or fourth root transformation where necessary (Table 5). Fish abundance $\left(N_{\mathrm{T}}\right)$ and biomass $\left(B_{\mathrm{T}}\right)$ increased from AM toward VM independently of the period considered, while values from BA were intermediate. Dominance displayed significant differences among these groups, but pair-wise tests were inconclusive. By contrast, species equitability $\left(N_{21}\right)$ was consistently lower in VM than in either BA or AM, which did not differ from each other. The abundance ratio between labrids and sparids $\left(N_{\mathrm{L} / \mathrm{S}}\right)$ was significantly larger in $\mathrm{VM}$, and differences between AM and BA were only detected during the warm period. Regarding temporal withinyear patterns, the number of species $(S)$, diversity $\left(H^{\prime}\right)$, abundance $\left(N_{\mathrm{T}}\right)$ and evenness $\left(N_{21}\right)$ were higher in the cold period than in the warm period. Conversely, dominance $(\lambda)$ was higher in the warm period than in the cold period. The $N_{\mathrm{L} / \mathrm{s}}$ followed the opposite pattern, but only in BA and VM (Fig. 3).

The first (horizontal) canonical axis in the CCA plot explained $49.90 \%$ of the observed variability, and was mainly correlated with the environmental descriptors DC and DR $(|r|>0.5)$, while correlation values with the rest of the habitat variables were lower $(|r|<0.4)$. The second (vertical) axis explained $13.29 \%$ of the observed variability, and was mostly correlated with DPO, MCAR and $T(|r|>0.5)$ and to a lesser extent with the remaining descriptors $(|\mathrm{r}|<0.4)$. Vagile species were arranged on the right-hand quadrants, interpreted as 'reef isolation'. Sparids accounted for 6 out of 7 of these species, and a close association was found between Pagellus acarne and DC, as well as between Mullus barbatus and DR, and between Diplodus sargus and T. By contrast, the third quadrant indicated 'reef connectivity' and contained less motile species (gobies, blennies, labrids, Apogon imberbis, Scorpaena porcus and Serranus scriba) as well as $M$. surmuletus. Three other species appeared on the boundary between the second and third quadrants (Oblada melanura, Symphodus cinereus and Spicara smaris) closely associated with MCAR and $T$ (Fig. 4). The permutation test confirmed the non-randomness of the ordination obtained $\left(\delta^{2}=8061, \mathrm{p}<0.001\right)$.
Table 5. Permutational ANOVAs on number of species $(S)$, Shannon's diversity index $\left(H^{\prime}\right)$, Simpson's dominance index $(\lambda)$, Hill's evenness ratio $\left(N_{21}\right)$, total number of individuals $\left(N_{\mathrm{T}}\right)$, abundance ratio between labrids and benthic sparids $\left(N_{\mathrm{L} / \mathrm{S}}\right)$ and estimated total biomass in $\mathrm{g}\left(B_{\mathrm{T}}\right)$. Computations were based on Euclidean distances. Bold numbers indicate significant results with $\mathrm{p}<0.05$ after 9999 random permutations

\begin{tabular}{|c|c|c|c|c|c|c|}
\hline \multirow{2}{*}{ Variable } & \multicolumn{2}{|c|}{ Locality } & \multicolumn{2}{|c|}{ Period } & \multicolumn{2}{|c|}{ Locality $\times$ Period } \\
\hline & $F_{2,2}$ & $\mathrm{p}$ & $F_{1,2}$ & $\mathrm{p}$ & $F_{2,30}$ & $\mathrm{p}$ \\
\hline$S$ & 7.50 & 0.1237 & 21.35 & 0.0001 & 1.58 & 0.2244 \\
\hline$H^{\prime}$ & 2.92 & 0.0698 & 28.40 & 0.0001 & 0.20 & 0.8284 \\
\hline$\lambda$ & 6.53 & 0.0041 & 29.27 & 0.0001 & 0.35 & 0.7134 \\
\hline$N_{21}$ & 10.38 & 0.0002 & 13.80 & 0.0018 & 1.28 & 0.2950 \\
\hline $\ln \left(N_{\mathrm{T}}+1\right)$ & 24.57 & 0.0356 & 13.73 & 0.0010 & 1.51 & 0.2427 \\
\hline$\sqrt{ }\left(N_{\mathrm{L} / \mathrm{S}}+1\right)$ & 36.45 & 0.0247 & 4.21 & 0.0370 & 3.84 & 0.0334 \\
\hline $\ln \left(B_{\mathrm{T}}+1\right)$ & 11.89 & 0.0001 & 0.09 & 0.7690 & 0.29 & 0.7473 \\
\hline
\end{tabular}

\section{DISCUSSION}

Our results show that the fish assemblages inhabiting identical reefs in distinct localities differed in several ways. Total abundance consistently segregated the fish assemblages among localities, while total fish biomass and species evenness segregated the assemblages of localities with the most extreme conditions (BA and VM) throughout the year. Species composition, their relative abundance and multispecies variability discriminated the assemblages in most cases. Putting all results together, reef fish assemblages were typical for each locality. 

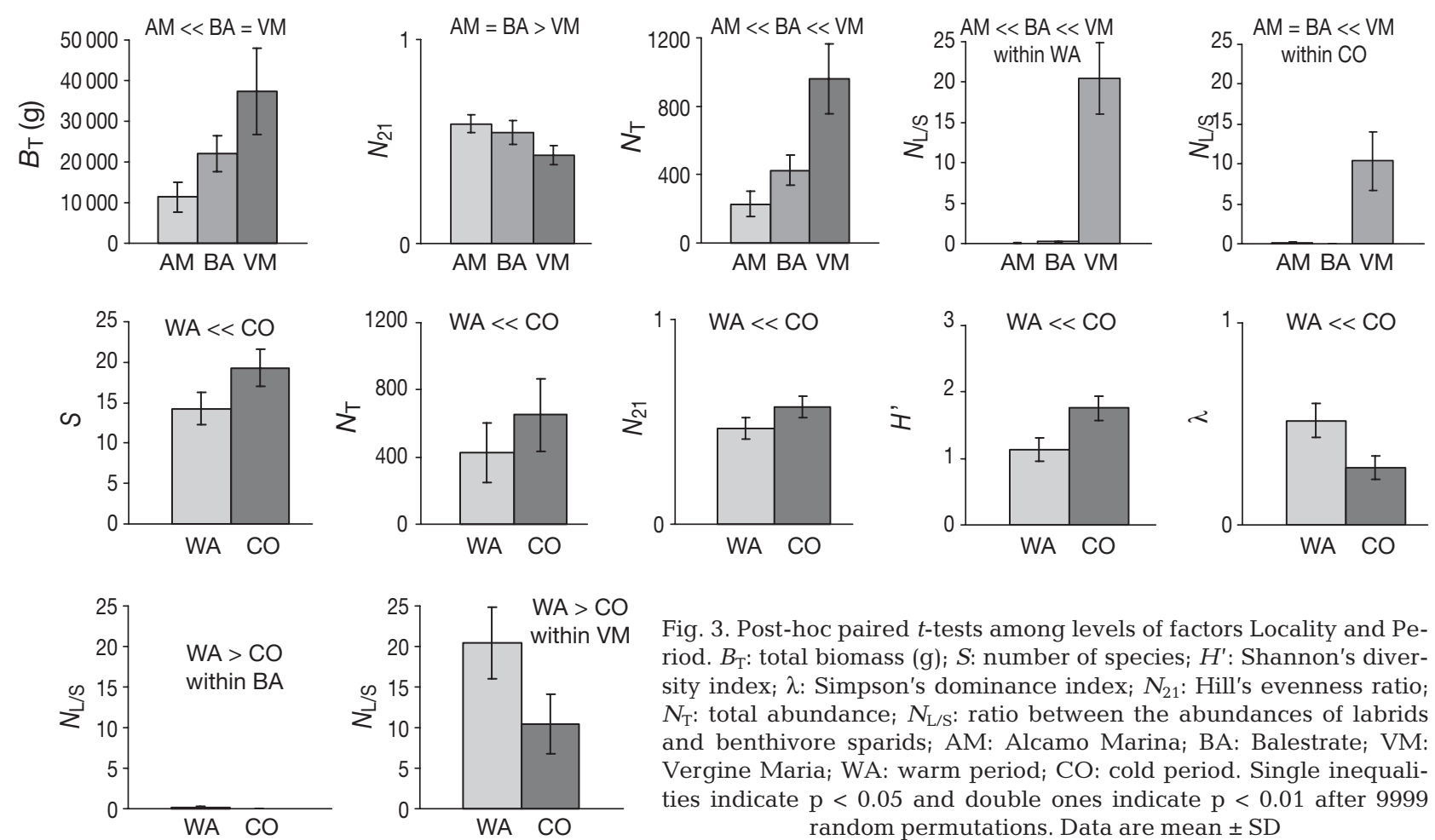

Fig. 3. Post-hoc paired $t$-tests among levels of factors Locality and Period. $B_{\mathrm{T}}$ : total biomass (g); $S$ : number of species; $H^{\prime}$ : Shannon's diversity index; $\lambda$ : Simpson's dominance index; $N_{21}$ : Hill's evenness ratio; $N_{\mathrm{T}}$ : total abundance; $N_{\mathrm{L} / \mathrm{S}}$ : ratio between the abundances of labrids and benthivore sparids; AM: Alcamo Marina; BA: Balestrate; VM: Vergine Maria; WA: warm period; CO: cold period. Single inequalities indicate $\mathrm{p}<0.05$ and double ones indicate $\mathrm{p}<0.01$ after 9999 random permutations. Data are mean $\pm \mathrm{SD}$

Reefs clearly differed among localities and this difference seems to be related to their different degree of connectivity with other complex habitats. These findings are in line with those of studies on coral reefs (Walsh 1985, Lewis 1997, Ault \& Johnson 1998b, Nanami \& Nishihira 2003a,b, Belmaker et al. 2005). Assemblage variability, however, was found to behave differently from that reported in the current literature.

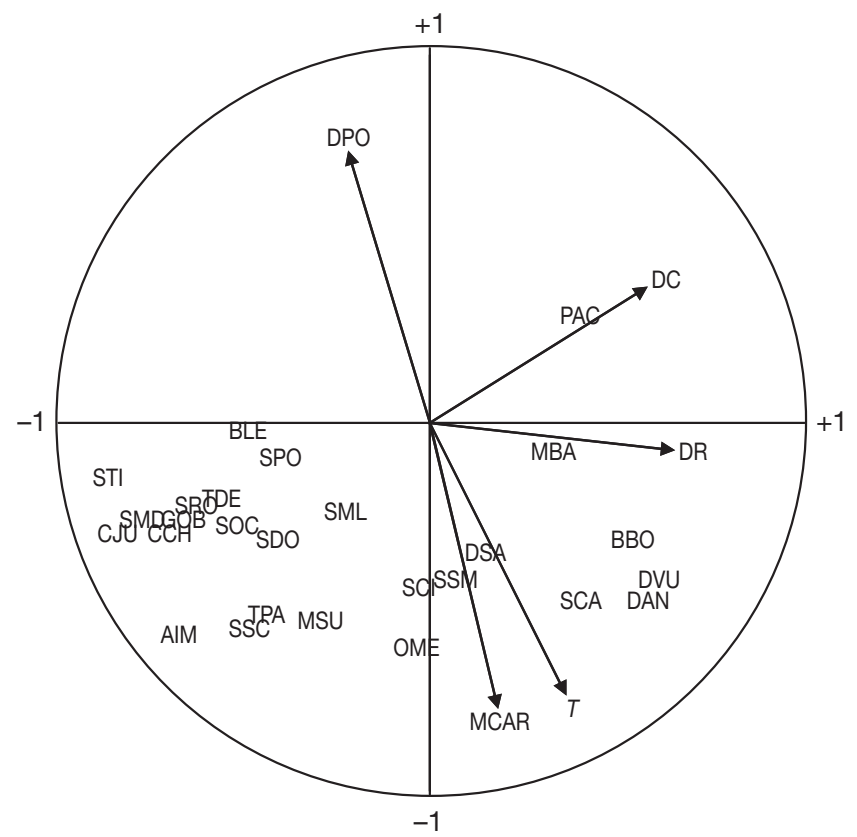

This disparity may be attributed to the contribution of fauna from adjacent habitats (uncontrolled 'edge effect') of previous studies (Ault \& Johnson 1998a, Ries et al. 2004) and to differences in the spatial scales (Levin 1992, Sale 1998). Although our results are generally in line with those reported by other authors, site-related factors cannot be completely excluded in explaining the observed pattern.

Fig. 4. Plot of the canonical correlation analysis (CCA) on those variables showing a correlation value of $|r| \geq 0.3$ with any canonical axes and present in at least 9 samples. AIM:Apogon imberbis, BLE: Blennidae, BBO: Boop boops, CCH: Chromis chromis, CJU: Coris julis, DAN: Diplodus annularis, DC: distance from coast (m), DPO: distance from $P$. oceanica beds (m), DR: distance from rocky beds (m), DSA: Diplodus sargus, DVU: Diplodus vulgaris, GOB: Gobiidae, MBA: Mullus barbatus, MCAR: mean connectivity among artificial reef units, MSU: Mullus surmuletus, OME: Oblada melanura, PAC: Pagellus acarne, SCA: Spondyliosoma cantharus, SCI: Symphodus cinereus, SDO: Symphodus doderleini, SMD: Symphodus mediterraneus, SML: Symphodus melanocercus, SOC: Symphodus ocellatus, SPO: Scorpaena porcus, SRO: Symphodus rostratus, SSC: Serranus scriba, SSM: Spicara smaris, STI: Symphodus tinca, T: mean temperature $\left({ }^{\circ} \mathrm{C}\right), \mathrm{TPA}$ : Thalassoma pavo, TDE: Tripterygion delaisi 
Reef-attached (blennies, gobies, Apogon imberbis, Chromis chromis), less mobile (Scorpaena porcus) as well as territorial (labrids, Serranus scriba) species were associated with complex habitat continuity. The distribution of this group of species is possibly restricted to highly connected habitats because of the increased risk of predation when fishes move from one reef to another across bare areas (Walsh 1985, Belmaker et al. 2005). There is observational evidence that other small reef fish species avoid crossing sandy areas from tens (Chapman \& Kramer 2000, Nanami \& Nishihira 2003b) to $100 \mathrm{~s}$ of meters wide (Frederick 1997), while able to do so (Thompson 1979, 1983 in Jones 1988, Lewis 1997).

In contrast, mobile, off-reef foragers were associated with low connectivity among complex habitats. These were mainly benthivore sparids, as supported by previous studies (e.g. Harmelin 1987). Robust evidence is, however, limited to Diplodus sargus: tracked individuals of this species moved daily over the sandy matrix, 100s of meters from the reef (V. M. Giacalone unpubl. data); gut contents reveal that most prey of D. sargus originate from the sand plateau (Pepe et al. 1998).

Support for the trends described above was also provided by the 2 mullid species in the present study. Mullus surmuletus was associated with 'reef connectivity', in line with previous studies that located this species in rough bottoms (Hureau 1986) and ecotones (Bell \& Harmelin-Vivien 1983, De Pirro et al. 1999). By contrast $M$. barbatus was associated with 'reef isolation', in agreement with authors who reported this species on extensive soft bottoms (Larrañeta \& RodríguezRoda 1956, Hureau 1986). Our findings are in close concordance with a long-known segregation in feeding behavior and habitat use between these similar, sympatric species (Rizzo 1931, Vassilopoulou et al. 2001).

The ratio between the abundance of labrids and benthivore sparids summarizes the patterns described above. This ratio was large in reefs for the locality where habitat connectivity was highest and progressively decreased in those localities presenting medium or low habitat connectivity. Although these families belong to the same broad trophic group, they display dissimilar vagility, moving at different spatial scales (Harmelin 1987). Movement of post-settled individuals to the reef from surrounding habitats has been described elsewhere (Matthews 1985, Jones 1988, Lewis 1997). Post-settlement immigration plays an important role in the persistence of patch-reef populations because mortality is high in assemblages concentrated around 'outcrops' (Bohnsack 1996, Nanami \& Nishihira 2003a). The relocation ability of juveniles and adults, and the degree of connectivity among suitable habitat patches, would hence determine the intensity of the fluxes among reef populations. As a result, localities in which reefs present different degrees of connectivity with other patches of suitable habitat host different proportions of species that vary in vagility.

Clearly, these findings are limited by the fact that each locality in our study represents a unique experimental condition. The restricted availability of ARAs composed of identical reef units under similar conditions precluded the possibility of replication for this factor. This leads to potential confounding between connectivity and other factors naturally varying among localities. Water turbidity and algal cover have previously been noted as main factors influencing the benthic fauna of the study area (D'Anna et al. 2000, Badalamenti et al. 2002). The pattern of water turbidity is opposite to that of total fish abundance and some relationship between them could be supposed. However, studies on the response of fishes to water turbidity reported that, to produce an effect, differences between the levels of this factor should be much higher than those present in our study area (Cyrus \& Blaber 1987 and references therein), making this relationship unlikely. Chang (1985) did not find notable differences in the abundance of large fish in artificial reefs placed in clear (>10 $\mathrm{m}$ visibility) and turbid waters $(<1 \mathrm{~m})$, although he found differences in the composition of the benthic communities. Algal cover is known to influence the abundance of small labrids in austral temperate reefs (Jones 1988). In the present study, the gradient of algal cover across ARAs does not correlate with the patterns displayed by the fish assemblages. In particular, the labrids and sparids abundance ratio does not follow the trend of algal cover. Of course, a non-linear (e.g. threshold) response could also be involved here. Nevertheless, the abundances of most temperate reef fishes appear mainly correlated to coarse topographical complexity rather than smallscale features, except in those habitats dominated by the very large kelp algae (Jones 1988). These considerations suggest that habitat connectivity is the main factor explaining the observed differences among the fish assemblages studied.

Our results support the model in which connectivity among complex habitat patches determines the structure of the reef fish assemblages, which is well summarized by the ratio between sparids and labrids. These families responded differently to a typical Mediterranean coastal landscape, made up of alternating rocks, seagrass beds and sandy bottoms. Our result indicates that fish perception of this landscape varied in terms of spatial scale $(10 \mathrm{~s}, 100 \mathrm{~s}$ and 1000s of meters) and habitat quality (ability to cross and exploit the sandy matrix). The findings agree with the hypotheses advanced by Ault \& Johnson (1998a) on habitat use by distinct reef fishes, and support the role of the sand matrix as a barrier of variable permeability for species 
and size (Bell \& Westoby 1986, Stamps et al. 1987, Lewis 1997, Coll et al. 1998).

Some of the descriptors of the fish assemblage structure also varied within the year. Species composition and their relative abundances, number of species, diversity and evenness and total fish abundance were higher in the cold than in the warm period. Accordingly, dominance followed the opposite trend. Multispecies variability was higher during the cold period in all but one locality. The effect of seasonality on fish assemblages has been reported by several authors. Ebeling \& Hixon (1991) found differences comparing scales of temporal variability in temperate and coral reef assemblages. In the Mediterranean, temporal patterns in fish assemblages have been studied by Francour (1997) and Guidetti et al. (2003). While our results disagree with these authors they are in concordance with those of Matthews (1990) and Bayle Sempere et al. (1994) in finding more species and individuals during the cold period. The distinct contribution of transient (non persistent) species, which change habitat throughout the year, is a clear component of this pattern (Matthews 1990).

Two complementary hypotheses are proposed here to explain our findings. Firstly, the trophic nature of our studied system differs from those of most work in the Mediterranean. In our study area, a large quantity of particulate and dissolved organic matter comes from rivers (Genchi et al. 1983, Calvo \& Genchi 1989). In line with this, 2 species linked to planktonic production in our study (Spicara smaris and Oblada melanura) were more abundant during the cold (rainy) season, suggesting drainage from the extensive cultivated areas and wave-induced resuspension as the major factors driving primary production in sheltered areas. This landscape-level dynamic may explain the contrast between our findings and those of Guidetti et al. (2003). These authors worked on a less sheltered coast and reported higher abundances of particulate feeders and planktivorous fishes in (dry) summer, in correlation with the increase in wastewater from tourist resorts.

Secondly, sport fishing may cause the drop in fish abundance observed during the warm period. Fishing effort is high in this period, and concentrates on the artificial structures where fishes are easily located and caught (Bohnsack 1996). This may account for the difference from the pattern reported by Francour (1997), who worked on the extensive Posidonia oceanica seagrass beds of a marine reserve. In fact, when artificial reefs were deployed on another $P$. oceanica seagrass bed and exploited by local fisheries, a temporal trend close to ours was found (Bayle Sempere et al. 1994).

The temporal trends reported here were also supported by the abundance ratio between labrids and sparids, which was larger in the warm period than in the cold. The contribution of young individuals seems to be of particular importance in this trend, as juveniles of these families were observed to arrive in different periods. Labrids were the only fish recorded at very small sizes (under $2 \mathrm{~cm} \mathrm{TL}$ ), suggesting that some of them recruit directly onto the reefs during the warm period. By contrast, sparids of the genus Diplodus spent the first months of their juvenile phase in shallow areas that they later leave (MacPherson 1998), reaching the studied reefs by late autumn as individuals of $>6 \mathrm{~cm}$ TL (authors' pers. obs.). The abundance of small individuals would be expected to decrease sharply following their arrival on the reefs. Therefore, the respective 'pulses' of young-of-the-year would drive the ratio up and down throughout the year. The development of aquaculture and port facilities in the study area during the years following our research prevented further temporal replication. Further experiments are therefore required to generalize these results.

In conclusion, we have found that fish assemblages varied among reefs in localities characterized by different connectivity among complex habitat patches. Some descriptors of the assemblage structure (total fish abundance, biomass and species equitability) discriminated the assemblages independently of the time of year considered, while others (species composition, their relative abundances and variability, as well as the abundance ratio between labrids and sparids) interacted with time. Finally, some attributes of the assemblages (number of species, evenness and abundance) also varied consistently between periods regardless of the locality studied. Differences in the vagility of the species seem to be responsible for this pattern, as well as the presence of vagrant species in certain periods. These complex patterns were well exemplified by the abundance ratio between 2 families of benthivore fishes: sparids and labrids.

The present study provides insight into the importance of habitat connectivity for fishes at a larger spatial scale than those of other manipulative works. Our findings thus contribute to filling an information gap, as patterns are scale-dependent (Levin 1992) and results from small-scale studies do not necessarily apply to larger spatial scales (Sale 1998). Our findings agree with those of other authors (Lewis 1997, Dorenbosch et al. 2007) in highlighting the role of habitat connectivity for reef fish faunas. This knowledge is critical in order to plan correct conservation and management strategies.

Acknowledgements. The authors thank Vincenzo Maximiliano Giacalone for making unpublished data available, Marilena Coppola and Giuseppe Di Stefano for their laboratory assistance, and Helen Main for help with the English. 


\section{LITERATURE CITED}

Alatalo RV (1981) Problems in the measurement of evenness in ecology. Oikos 37:199-204

Ambrose RF, Anderson TW (1990) Influence of an artificial reef on the surrounding infaunal community. Mar Biol 107:41-52

Ault TR, Johnson CR (1998a) Spatially and temporally predictable fish communities on coral reefs. Ecol Monogr 68:25-50

Ault TR, Johnson CR (1998b) Spatial variation in fish number of species on coral reefs: habitat fragmentation and stochastic structuring processes. Oikos 82:354-364

Badalamenti F, Chemello R, D'Anna G, Henríquez Ramos P, Riggio S (2002) Are artificial reefs comparable to neighbouring natural rocky areas? A mollusc case study in the Gulf of Castellammare. ICES J Mar Sci 59:S127-S131

Bayle-Sempere JT, Ramos-Esplá AA, García-Charton JA (1994) Intra-annual variability of an artificial reef fish assemblage in the marine reserve of Tabarca (Alicante, Spain, SW Mediterranean). Bull Mar Sci 55:824-835

Beets J, Muehlstein L, Haught K, Schmitges H (2003) Habitat connectivity in coastal environments: patterns and movements of Caribbean coral reef fishes with emphasis on bluestripped grunt, Haemulon sciurus. Gulf Caribb Res 14:29-42

Bell JD, Harmelin-Vivien ML (1983) Fish fauna of French Mediterranean Posidonia oceanica seagrass meadows. 2. Feeding habits. Tethys 11:1-14

Bell JD, Westoby M (1986) Variation in seagrass height and density over a wide spatial scale: effects on common fish and decapods. J Exp Mar Biol Ecol 104:275-295

Belmaker J, Shashar N, Ziv Y (2005) Effects of small-scale isolation and predation on fish diversity on experimental reefs. Mar Ecol Prog Ser 289:273-283

Bohnsack JA (1996) Maintenance and recovery of reef fishery productivity. In: Polunin NVC, Roberts CM (eds) Reef fisheries. Chapman \& Hall, London.

Calvo S, Genchi G (1989) Carico organico ed effetti eutrofici nel Golfo di Castellammare (Sicilia Nord occidentale). Oebalia 15(S1):397-408

Chang KH (1985) Review of artificial reefs in Taiwan: emphasizing site selection and efectiveness. Bull Mar Sci 37:143-150

> Chapman MR, Kramer DL (2000) Movements of fishes within and among fringing coral reefs in Barbados. Environ Biol Fishes 57:11-24

Coll J, Moranta J, Reñones O, García-Rubies A, Moreno I (1998) Influence of substrate and deployment time on fish assemblages on an artificial reef at Formentera Island (Balearic Islands, western Mediterranean). Hydrobiologia 385:139-152

Cyrus DP, Blaber SJM (1987) The influence of turbidity on juvenile marine fishes in estuaries. Part 2. Laboratory studies, comparisons with field data and conclusions. J Exp Mar Biol Ecol 109:71-91

D'Anna G, Badalamenti F, Riggio S (2000) Artificial reefs in North West Sicily: comparisons and conclusions. In: Jensen AC, Collins KJ, Lockwood APM (eds) Artificial reefs in European seas. Kluwer, Dordrecht

$>$ De Pirro M, Marchetti GM, Chelazzi G (1999) Foraging interactions among three benthic fish in a Posidonia oceanica reef lagoon along the Tyrrhenian Coast. J Fish Biol 54: 1300-1309

Dorenbosch M, Verberk WCEP, Nagelkerken I, van der Velde G (2007) Influence of habitat configuration on connectivity between fish assemblages of Caribbean seagrass beds, mangroves and reefs. Mar Ecol Prog Ser 334:103-116

Ebeling AW, Hixon MA (1991) Tropical and temperate reef fishes: comparison of community structures. In: Sale PF (ed) The ecology of fishes on coral reefs. Academic Press,
San Diego, CA

Fahrig L (2003) Effects of habitat fragmentation on biodiversity. Annu Rev Ecol Evol Syst 34:487-515

Francour P (1997) Fish assemblages of Posidonia oceanica beds at Port-Cros (France, NW Mediterranean): assessment of composition and long term fluctuations by visual census. PSZNI: Mar Ecol 18:157-173

Frederick JL (1997) Post-settlement movement of coral reef fishes and bias in survival estimates. Mar Ecol Prog Ser 150:65-74

Genchi G, Lugaro A, Calvo S, Ragonese S (1983) Ecologia del Golfo di Palermo. I. Risultati preliminari su nutrienti, clorofilla, proteine e glucidi particellati. Nat Sicil 4(S3):553-571

Guidetti P (2000) Differences among fish assemblages associated with nearshore Posidonia oceanica seagrass beds, rocky-algal reefs and unvegetated sand habitats in the Adriatic Sea. Estuar Coast Shelf Sci 50:515-529

Guidetti P, Terlizzi A, Fraschetti S, Boero F (2003) Changes in Mediterranean rocky-reef fish assemblages exposed to sewage pollution. Mar Ecol Prog Ser 253:269-278

Harmelin JG (1987) Structure et variabilité de l'ichtyofaune d'une zone rocheuse protégée en Méditerranée (Parc national de Port-Cros, France). PSZNI: Mar Ecol 8:263-284

Hobson ES (1972) Activity of Hawaiian reef fishes during the evening and morning transitions between daylight and darkness. Fish Bull (Wash DC) 70:715-740

Hureau JC (1986) Mullidae. In: Whitehead PJP, Bauchot ML, Hureau JC, Nielsen J, Tortonese E (eds) Fishes of the North-eastern Atlantic and Mediterranean, Vol 2. UNESCO, Bungay

Jones GP (1988) Ecology of rocky reef fish of north-eastern New Zealand: a review. NZ J Mar Freshw Res 22:445-462

Langlois TJ, Anderson MJ, Babcock RC (2005) Reef-associated predators influence adjacent soft-sediment communities. Ecology 86:1508-1519

Larrañeta MG, Rodríguez-Roda J (1956) Contribución al conocimiento de la pesquería del salmonete de fango (Mullus barbatus L.) de las costas de Castellón. Investig Pesq 3:45-68

Levin SA (1992) The problem of pattern and scale in ecology. Ecology 73:1943-1967

Lewis AR (1997) Recruitment and post-recruit immigration affect the local population size of coral reef fishes. Coral Reefs 16:139-149

MacPherson E (1998) Ontogenetic shifts in habitat use and aggregation in juvenile sparid fishes. J Exp Mar Biol Ecol 220:127-150

Matthews KR (1985) Species similarity and movement of fishes on natural and artificial reefs in Monterrey Bay, California. Bull Mar Sci 37:252-270

Matthews KR (1990) An experimental study of the habitat preferences and movement patters of copper, quillback, and brown rockfishes (Sebastes spp.). Environ Biol Fishes 29:161-178

McClanahan TR, Mangi S (2000) Spillover of exploitable fishes from a marine park and its effect on the adjacent fishery. Ecol Appl 10:1792-1805

Miller MW (2002) Using ecological processes to advance artificial reef goals. ICES J Mar Sci 59:S27-S31

Nanami A, Nishihira M (2003a) Population dynamics and spatial distribution of coral reef fishes: comparison between continuous and isolated habitats. Environ Biol Fishes 68:101-112

Nanami A, Nishihira M (2003b) Effects of habitat connectivity on the abundance and number of species of coral reef fishes: comparison of an experimental habitat established at a rocky reef flat and at a sandy sea bottom. Environ Biol 
Fishes 68:183-196

Pepe P, Badalamenti F, D'Anna G (1998) Feeding habits of Diplodus sargus in the artificial reef area of Alcamo Marina (Gulf of Castellammare, North-western Sicily). Biol Mar Mediterr 5:367-370

Ries L, Fletcher RJ, Battin J, Sisk TD (2004) Ecological responses to habitat edges: mechanisms, models, and variability explained. Annu Rev Ecol Syst 35:491-522

Rizzo L (1931) Contributo allo studio dell'alimentazione nei pesci Mullus barbatus L. e Mullus surmuletus L. Boll Pesca Piscic Idrobiol 7:899-905

Robertson DR (1988) Abundances of surgeonfishes on patchreefs in Caribbean Panamá: due to settlement, or postsettlement events? Mar Biol 97:495-501
Sale PF (1998) Appropriate spatial scales for studies of reeffish ecology. Aust J Ecol 23:202-208

Stamps JA, Buecher M, Krishnan VV (1987) The effects of edge permeability and habitat geometry on emigration from patches of habitat. Am Nat 129:533-552

Talbot FH, Russell B, Anderson GRV (1978) Coral reef fish communities: unstable, high-diversity systems? Ecol Monogr 48:425-440

Vassilopoulou V, Papaconstantinou C, Christides G (2001) Food segregation of sympatric Mullus barbatus and Mullus surmuletus in the Aegean Sea. Isr J Zool 47:201-211

Walsh WJ (1985) Reef fish community dynamics on small artificial reefs: the influence of isolation, habitat structure, and biogeography. Bull Mar Sci 36:357-376

Appendix 1. List of recorded species and frequencies of occurrence within each level of factors Locality and Period in 36 samples. T: transient; P: persistent; AM: Alcamo Marina; BA: Balestrate; VM: Vergine Maria; WA: warm period; CO: cold period

\begin{tabular}{|c|c|c|c|c|c|c|c|}
\hline \multirow{2}{*}{ Family } & \multirow{2}{*}{ Species } & \multirow{2}{*}{ Category } & \multicolumn{3}{|c|}{ Locality } & \multicolumn{2}{|c|}{ Period } \\
\hline & & & $\mathrm{AM}$ & BA & VM & WA & $\mathrm{CO}$ \\
\hline Synodontidae & Synodus saurus & $\mathrm{T}$ & & & 0.08 & 0.06 & \\
\hline Muraenidae & Muraena helena & $\mathrm{P}$ & & & 0.25 & 0.06 & 0.11 \\
\hline Congridae & Conger conger & $\mathrm{P}$ & 0.17 & 0.33 & 0.17 & 0.17 & 0.28 \\
\hline Gadidae & Phycis phycis & $\mathrm{T}$ & 0.17 & 0.25 & & & 0.28 \\
\hline \multirow{4}{*}{ Serranidae } & Serranus cabrilla & $\mathrm{P}$ & 0.92 & 0.92 & 1.00 & 0.94 & 0.94 \\
\hline & Serranus scriba & $\mathrm{P}$ & 0.50 & 1.00 & 1.00 & 0.72 & 0.94 \\
\hline & Epinephelus aeneus & $\mathrm{T}$ & 0.08 & 0.08 & & & 0.11 \\
\hline & Epinephelus marginatus & $\mathrm{T}$ & & & 0.08 & & 0.06 \\
\hline Moronidae & Dicentrarchus labrax & $\mathrm{P}$ & 0.25 & & & 0.11 & 0.06 \\
\hline Apogonidae & Apogon imberbis & $\mathrm{P}$ & 0.58 & 1.00 & 1.00 & 0.78 & 0.94 \\
\hline \multirow{2}{*}{ Carangidae } & Seriola dumerili & $\mathrm{T}$ & 0.08 & 0.08 & & & 0.11 \\
\hline & Trachurus trachurus & $\mathrm{T}$ & 0.08 & & & & 0.06 \\
\hline Sciaenidae & Sciaena umbra & $\mathrm{P}$ & 0.33 & & & 0.06 & 0.17 \\
\hline \multirow{2}{*}{ Mullidae } & Mullus barbatus & $\mathrm{P}$ & 0.58 & 0.17 & 0.08 & 0.17 & 0.39 \\
\hline & Mullus surmuletus & $\mathrm{P}$ & 0.58 & 0.33 & 1.00 & 0.56 & 0.72 \\
\hline \multirow{9}{*}{ Sparidae } & Pagrus pagrus & $\mathrm{T}$ & 0.17 & 0.33 & & & 0.33 \\
\hline & Boops boops & $\mathrm{P}$ & 1.00 & 1.00 & 0.50 & 0.83 & 0.83 \\
\hline & Diplodus annularis & $\mathrm{P}$ & 1.00 & 1.00 & 0.67 & 0.78 & 1.00 \\
\hline & Diplodus sargus & $\mathrm{P}$ & 0.58 & 0.67 & 0.33 & 0.50 & 0.56 \\
\hline & Diplodus vulgaris & $\mathrm{P}$ & 1.00 & 1.00 & 0.92 & 0.94 & 1.00 \\
\hline & Lithognathus mormyrus & $\mathrm{P}$ & 0.17 & 0.25 & & 0.17 & 0.11 \\
\hline & Oblada melanura & $\mathrm{T}$ & 0.08 & 0.42 & 0.50 & & 0.67 \\
\hline & Pagellus acarne & $\mathrm{P}$ & 0.67 & 0.25 & 0.08 & 0.33 & 0.33 \\
\hline & Spondyliosoma cantharus & $\mathrm{P}$ & 0.50 & 0.42 & 0.17 & 0.11 & 0.61 \\
\hline \multirow[t]{3}{*}{ Centracanthidae } & Spicara maena & $\mathrm{P}$ & 0.42 & 0.67 & 0.17 & 0.56 & 0.28 \\
\hline & Spicara flexuosa & $\mathrm{T}$ & 0.17 & 0.25 & 0.08 & & 0.33 \\
\hline & Spicara smaris & $\mathrm{P}$ & 0.25 & 0.42 & 0.50 & 0.22 & 0.56 \\
\hline Pomacentridae & Chromis chromis & $\mathrm{P}$ & 1.00 & 1.00 & 1.00 & 1.00 & 1.00 \\
\hline \multirow[t]{10}{*}{ Labridae } & Coris julis & $\mathrm{P}$ & 0.25 & 0.58 & 1.00 & 0.61 & 0.61 \\
\hline & Symphodus rostratus & $\mathrm{P}$ & 0.17 & & 0.92 & 0.33 & 0.39 \\
\hline & Symphodus cinereus & $\mathrm{P}$ & 0.42 & 0.42 & 0.42 & 0.33 & 0.50 \\
\hline & Symphodus doderleini & $\mathrm{P}$ & & & 0.83 & 0.22 & 0.33 \\
\hline & Symphodus mediterraneus & $\mathrm{P}$ & 0.25 & 0.08 & 1.00 & 0.33 & 0.56 \\
\hline & Symphodus melanocercus & $\mathrm{P}$ & 0.25 & & 0.50 & 0.11 & 0.39 \\
\hline & Symphodus ocellatus & $\mathrm{P}$ & 0.25 & & 0.75 & 0.33 & 0.33 \\
\hline & Symphodus roissali & $\mathrm{T}$ & & & 0.17 & & 0.11 \\
\hline & Symphodus tinca & $\mathrm{P}$ & 0.33 & 0.58 & 1.00 & 0.78 & 0.50 \\
\hline & Thalassoma pavo & $\mathrm{P}$ & 0.58 & 0.67 & 0.83 & 0.61 & 0.78 \\
\hline Scaridae & Sparisoma cretense & $\mathrm{T}$ & & & 0.08 & & 0.06 \\
\hline Gobiidae & Gobius spp. & $\mathrm{P}$ & 0.17 & 0.17 & 0.92 & 0.39 & 0.44 \\
\hline Blenniidae & Parablennius spp. & $\mathrm{P}$ & 0.08 & 0.25 & 0.58 & 0.33 & 0.28 \\
\hline Tripterygiidae & Tripterygion delaisi & $\mathrm{P}$ & & & 0.75 & 0.22 & 0.28 \\
\hline \multirow[t]{3}{*}{ Scorpaenidae } & Scorpaena porcus & $\mathrm{P}$ & & 0.58 & 0.67 & 0.44 & 0.39 \\
\hline & Scorpaena notata & $\mathrm{T}$ & 0.08 & 0.33 & 0.25 & & 0.44 \\
\hline & Scorpaena scrofa & $\mathrm{P}$ & & 0.17 & 0.17 & 0.11 & 0.11 \\
\hline No. of samples (n) & & & 12 & 12 & 12 & 18 & 18 \\
\hline
\end{tabular}

